\title{
Angiotensin I-Converting Enzyme Inhibitor Derived from an Enzymatic Hydrolysate of Casein. II. Isolation and Bradykinin-potentiating Activity on the Uterus and the Ileum of Rats
}

\author{
Susumu Maruyama, Kazuya Nakagomi, Noboru Tomizuka \\ and Hideo SuZuKI
}

Fermentation Research Institute, Yatabe, Tsukuba, Ibaraki 305, Japan

Received October 8, 1984

\begin{abstract}
Inhibitors of angiotensin I-converting enzyme were isolated from an enzymatic hydrolysate of bovine casein. The amino acid sequences of these inhibitors were Phe-Phe-Val-Ala-Pro-Phe-ProGlu-Val-Phe-Gly-Lys $\left(\mathrm{CEI}_{12}\right)$, Phe-Phe-Val-Ala-Pro $\left(\mathrm{CEI}_{5}\right)$, and Ala-Val-Pro-Tyr-Pro-Gln-Arg $\left(\mathrm{CEI}_{\beta 7}\right) . \mathrm{CEI}_{5}$ is a penta-peptide derived from the hydrolysate of $\mathrm{CEI}_{12}$ with proline-specific endopeptidase, and $\mathrm{CEI}_{\beta 7}$ is a hepta-peptide derived from $\beta$-casein. These inhibitors potentiated bradykinin in the contraction of the uterus and the ileum of rats. The ileum was more sensitive to these inhibitors than the uterus. The bradykinin-potentiating activity of these inhibitors on the ileum lasted for more than 90 min even after washing the organ.
\end{abstract}

Angiotensin I-converting enzyme [kininase II, peptidyldipeptide hydrolase, EC 3.4.15.1] (ACE) catalyzes both the production of the vasoconstrictor angiotensin II and the inactivation of the vasodilator bradykinin.

ACE inhibitors were first discovered in snake venom. ${ }^{1,2)}$ All of the ACE inhibitors from snake venom have both ACE inhibitory and bradykinin-potentiating activities. Ondetti et al. developed captopril (D-3-mercapto-2methylpropanoyl-L-proline), an orally effective inhibitor, based upon a hypothetical model of the binding site on the enzyme, ${ }^{3)}$ and many workers also developed many such inhibitors. $^{4,5)}$

We found a peptide inhibitor of ACE $\left(\mathrm{CEI}_{12}\right.$, Phe-Phe-Val-Ala-Pro-Phe-Pro-GluVal-Phe-Gly-Lys) from the tryptic hydrolysate of bovine casein, ${ }^{6)}$ and now we have isolated other ACE inhibitors from the hydrolysate that are more potent than $\mathrm{CEI}_{12}$.

This report is on the isolation of these inhibitors and their effects as bradykininpotentiators on the uterus and the ileum of rats.

\section{MATERIALS AND METHODS}

Materials. Bradykinin, bradykinin-potentiator B, bradykinin-potentiator $\mathrm{C}^{2)}$ and hippuryl-L-histidyl-Lleucine were purchased from the Protein Research Foundation, Osaka, Japan; bradykinin-potentiating nonapeptide SQ20881 ${ }^{1)}$ was from Peninsula Laboratories Co. Rabbit lung acetone powder was obtained from Sigma Chemicals Co., Proline-specific endopeptidase from Flavobacterium meningosepticum was from Seikagaku Kogyo Co., Ltd., Japan; trypsin was from P-L Biochemicals, Inc. and carboxypeptidase $Y$ was from Oriental Yeast Co., Ltd., Japan. Casein was the product of Wako Pure Chemical Co., Japan.

Assay of ACE inhibitor. The activity of the ACE inhibitor was assayed by a modification of the method of Cushman and Cheung as described in our previous report. ${ }^{6)}$ Five millimolar hippuryl-L-histidyl-L-leucine and ACE inhibitor were dissolved in $100 \mathrm{~mm}$ sodium borate buffer, $\mathrm{pH} 8.3$, containing $300 \mathrm{~mm} \mathrm{NaCl}$, and incubated with $8 \mathrm{~m}$ units $\mathrm{ACE}$ at $37^{\circ} \mathrm{C}$ for $30 \mathrm{~min}$. The concentration of ACE inhibitors needed to inhibit $50 \%$ of ACE activity was defined as the ID $_{50}$ value.

The ACE used in our experiments were crude, extracted from rabbit lung acetone powder, or partially purified with calcium phosphate gel and Sepharose 6B from crude ACE.

Isolation of $C E I_{\beta 7}$. One gram of casein from bovine milk 
was hydrolyzed with $2.5 \mathrm{mg}$ of trypsin from bovine pancreas by the method described in our previous report. ${ }^{6}$ ) After $18 \mathrm{hr}$ of digestion at $37^{\circ} \mathrm{C}$ the reaction was terminated by the addition of conc. $\mathrm{HCl}$ to $0.5 \mathrm{M}$ concentration. After the precipitate was removed by filtration, the supernatant was adjusted to $\mathrm{pH} 7.0$ with $\mathrm{NaOH}$. The hydrolysate was put on a Sephadex LH-20 column $(3 \times$ $112 \mathrm{~cm}$ ) and eluted with distilled water. The most active fraction was put in 2 batches on a SP-Sephadex C-25 column $(2 \times 47 \mathrm{~cm})$ and eluted with a linear gradient using $200 \mathrm{ml}$ each of distilled water and $0.5 \mathrm{M}$ ammonium formate ( $\mathrm{pH} 7.0$ ). Two active peaks were observed. The 1st peak was $\mathrm{CEI}_{12}$, and the 2 nd peak was further chromatographed with a Sephadex LH-20 column $(2 \times 62 \mathrm{~cm})$ and eluted with distilled water.

Isolation of $\mathrm{CEI}_{5}$. Four milligrams of $\mathrm{CEI}_{12}$ purified by the method described in our previous paper was dissolved in $1 \mathrm{ml}$ of phosphate buffer $(0.04 \mathrm{M}, \mathrm{pH} 7.0)$ and 2 units proline-specific endopeptidase was added. After $3 \mathrm{hr}$ of incubation at $37^{\circ} \mathrm{C}$, the enzyme was inactivated by boiling for $10 \mathrm{~min}$. The denatured enzyme was removed by ultrafiltration with CF25 (Amicon Co.). The hydrolyzed sample was put on a column (Radial-PAK $\mathrm{C}_{18}$, Waters Inc.) for high pressure liquid chromatography (HPLC). It was eluted at a flow rate of $1 \mathrm{ml} / \mathrm{min}$ with phosphate buffer (10 $\left.\mathrm{mm} \mathrm{KH}_{2} \mathrm{PO}_{4}, 50 \mathrm{~mm} \mathrm{Na}_{2} \mathrm{SO}_{4}, \mathrm{pH} 3.0\right) / \mathrm{CH}_{3} \mathrm{CN}(60: 40$, $\mathrm{v} / \mathrm{v})$ monitoring at $210 \mathrm{~nm}$. An active peak was collected and salts were removed by a Sep-PAK $\mathrm{C}_{18}$ cartridge (Waters Inc.).

Determination of amino acid sequences of $A C E$ inhibitors. The amino acid composition of each ACE inhibitor was analyzed with a Hitachi 835 high-speed amino acid analyzer after hydrolysis in $6 \mathrm{~N} \mathrm{HCl}$ at $110^{\circ} \mathrm{C}$ for $24 \mathrm{hr}$. Sequential analysis of $\mathrm{CEI}_{5}$ was done by a modification of the method of Edman. ${ }^{7}$ The $\mathrm{N}$ - and C-terminal amino acid sequences of $\mathrm{CEI}_{\beta 7}$ were determined by the direct method of Edman and by treatment with carboxypeptidase $\mathrm{Y}$, respectively.

Assay of the bradykinin-potentiating activity of ACE inhibitors on the uterus of rat. The bradykinin-potentiating activity of ACE inhibitors was measured on the isolated rat uterus. The uterus from a virgin rat ( 7 to 11 weeks old, Wistar) was mounted under $1 \mathrm{~g}$ load, in a $5-\mathrm{ml}$ muscle bath at $27^{\circ} \mathrm{C}$ containing aerated de Jalon solution $(\mathrm{NaCl}$ $152 \mathrm{~mm}, \mathrm{KCl} 5.6 \mathrm{~mm}, \mathrm{CaCl}_{2} 0.4 \mathrm{~mm}, \mathrm{NaHCO}_{3} 6.0 \mathrm{~mm}$, glucose $2.8 \mathrm{~mm}$ ). After mounting, the uterus was equilibrated for $30 \mathrm{~min}$ before the beginning of the experiments. ACE inhibitor was added before addition of standard bradykinin solution, and bradykinin induced contraction was measured with an isotonic transducer (Natsume Co., Ltd. KN-259).

Assay of the bradykinin-potentiating activity of $A C E$ inhibitors on the ileum of rat. The ileum from a rat (7 to 11 weeks old, Wistar) was mounted under $2 \mathrm{~g}$ load in a $5-\mathrm{ml}$ muscle bath at $30^{\circ} \mathrm{C}$ containing aerated Tyrode solution $\left(\mathrm{NaCl} 8.0 \mathrm{~g} /\right.$ liter, $\mathrm{KCl} 0.2 \mathrm{~g} /$ liter, $\mathrm{CaCl}_{2} 0.2 \mathrm{~g} /$ liter, $\mathrm{MgCl}_{2}$ $0.1 \mathrm{~g} /$ liter, $\mathrm{NaHCO}_{3} 1.0 \mathrm{~g} /$ liter, $\mathrm{NaH}_{2} \mathrm{PO}_{4} 0.05 \mathrm{~g} /$ liter, glucose $1.0 \mathrm{~g} /$ liter). The effects of the inhibitors were assayed in the same way as the uterus. 'Sensitizing activity' of the inhibitors was assayed according to a modification of the method of Kato and Suzuki ${ }^{2)}$ after washing the inhibitors out from the organ bath.

\section{RESULTS}

\section{Isolation of $\mathrm{CEI}_{\beta 7}$}

Isolation of $\mathrm{CEI}_{\beta 7}$ from the tryptic hydrolysate of casein was attempted by the procedure described in MATERIALS AND METHODS. Figure 1 shows the separation of $\mathrm{CEI}_{12}$ and $\mathrm{CEI}_{\beta 7}$ by SP-Sephadex C-25 from the active peak of Sephadex LH-20 chromatogram. Fractions of $\mathrm{CEI}_{\beta 7}$ were further fractionated with Sephadex LH-20 chromatography. The amino acid composition of $\mathrm{CEI}_{\beta 7}$ hydrolyzed with $6 \mathrm{~N} \mathrm{HCl}$ was: Ala (1.00), Val (0.95), Tyr (1.01), Arg (0.95), Pro (1.81), Glu (1.14). The amino acid sequence determined by the direct method of Edman and by digestion with carboxypeptidase $\mathrm{Y}$ is listed in Table $\mathrm{I}$. This heptapeptide corresponds to the sequence $177 \sim 183$ of $\beta$-casein.

\section{Isolation of $\mathrm{CEI}_{5}$}

Isolation of $\mathrm{CEI}_{5}$ was done as described in Materials and Methods. Figure 2 shows a HPLC chromatogram of a solution of $\mathrm{CEI}_{12}$ hydrolyzed with proline-specific endopeptidase. Potent inhibition appearing in the $3 \mathrm{rd}$ large peak (indicated as $\mathrm{CEI}_{5}$ ) was collected. The amino acid composition of $\mathrm{CEI}_{5}$ was: Ala (1.00), Val (1.10), Phe (1.84), Pro (0.90). The amino acid sequence determined by the direct method of Edman is also listed in Table I. This peptide was the 5 amino acid residues at the $\mathrm{N}$ terminal of $\mathrm{CEI}_{12}$.

The $\mathrm{ID}_{50}$ values of $\mathrm{CEI}_{\beta 7}$ and $\mathrm{CEI}_{5}$ in our assay condition using crude ACE as enzyme were $15 \mu \mathrm{M}$ and $6.0 \mu \mathrm{M}$, respectively. The $\mathrm{ID}_{50}$ value of ACE inhibitors determined using partially purified ACE ( 0.8 unit $/ \mathrm{mg}$ protein $)$ was about $9 / 10$ of the $\operatorname{ID}_{50}$ value determined using crude ACE. 


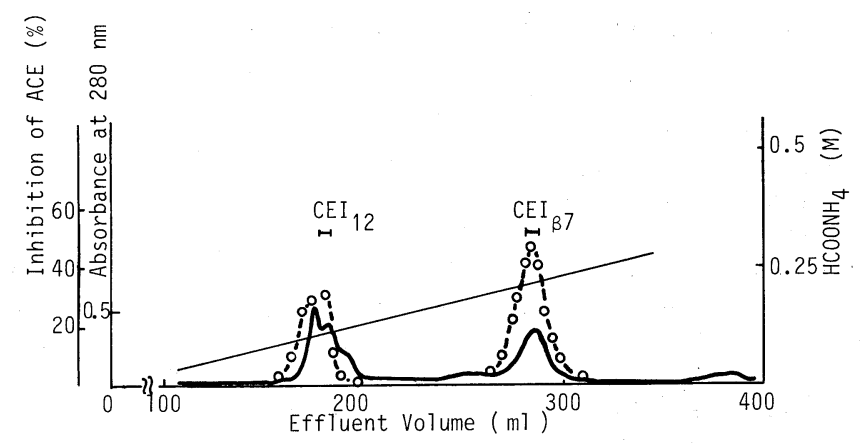

FIG. 1. Purification of $\mathrm{CEI}_{\beta 7}$ on a SP-Sephadex C-25 Column.

After gel filtration on Sephadex LH-20, the sample was chromatographed on a SP-Sephadex C-25 column $(2 \times 47 \mathrm{~cm})$ with linear gradient elution from 0 to $0.5 \mathrm{M}$ ammonium formate buffer, $\mathrm{pH} 7.0$. Eluate was collected as $4 \mathrm{ml}$ fractions at a flow rate of $24 \mathrm{ml} / \mathrm{hr}$. The effluent was assayed of inhibitory activity (-- $\left.\mathrm{O}_{--}\right)$, and absorbance at $280 \mathrm{~nm}$ was monitored with an ISCO UA5 absorbance monitor (- - ).

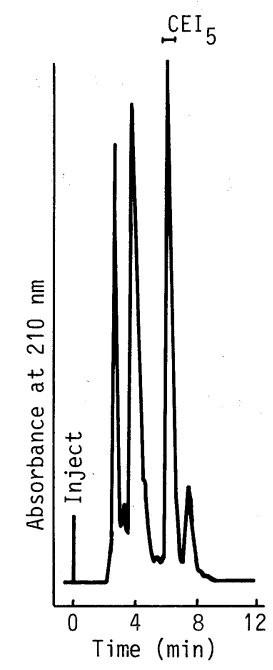

Fig. 2. Purification of $\mathrm{CEI}_{5}$ on a HPLC Column.

Twenty $\mu \mathrm{l}$ of the enzymatic hydrolysate of $\mathrm{CEI}_{12}$ by proline-specific endopeptidase was injected (see Materials AND Methods). The most active peak was collected (indicated as $\mathrm{CEI}_{5}$ ). Conditions for chromatograms: Column, Radial-PAK $\mathrm{C}_{18}(10 \mu)$; mobile phase, phosphate buffer (10 mM $\mathrm{KH}_{2} \mathrm{PO}_{4}, 50 \mathrm{~mm} \mathrm{Na} \mathrm{SO}_{4}, \mathrm{pH}$ $3.0) / \mathrm{CH}_{3} \mathrm{CN}(60: 40, \mathrm{v} / \mathrm{v})$; flow rate, $1 \mathrm{ml} / \mathrm{min}$; detector, UV $210 \mathrm{~nm}, 2.56$; sample, $20 \mu \mathrm{l}$.

\section{Bradykinin-potentiating activity of ACE inhib- itors on the rat uterus}

ACE inhibitors were tested by the contraction of the rat uterus for their bradykinin potentiation. Figure 3 shows SQ 20881, bradykinin-potentiator $\mathrm{B}$, and $\mathrm{CEI}_{12}$ increase the effect of bradykinin at the indicated concentration (i.e., $0.13 \times \mathrm{ID}_{50}$ value of each $\mathrm{ACE}$

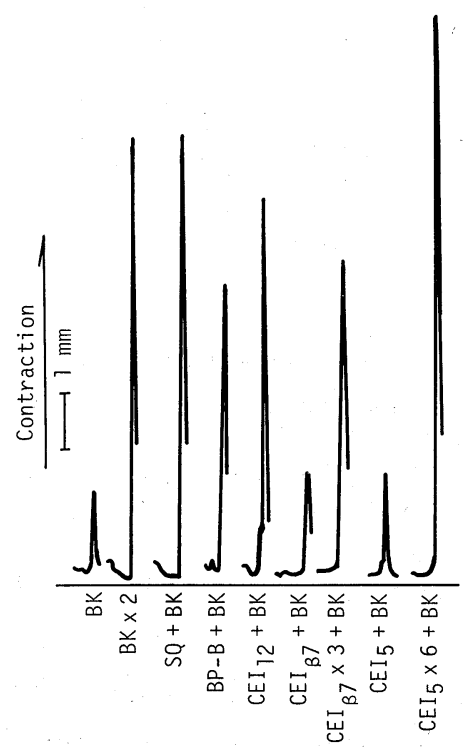

FIG. 3. Bradykinin-potentiating Activity of ACE Inhibitors on the Rat Uterus.

Bradykinin activity was measured by the contraction of the rat uterus in aerated de Jalon solution at $27^{\circ} \mathrm{C}$. For assay of bradykinin-potentiating activity, each ACE inhibitor (at the concentration of $0.13 \times \mathrm{ID}_{50}$ value) was added before addition of $4.0 \times 10^{-10} \mathrm{M}$ bradykinin. BK, bradykinin $4.0 \times 10^{-10} \mathrm{M} ; \mathrm{BK} \times 2$, bradykinin $8.0 \times 10^{-10}$ $\mathrm{M}$; SQ, SQ $208816.5 \times 10^{-8} \mathrm{M}$; BP-B, bradykinin-potentiator B $4.3 \times 10^{-7} \mathrm{M} ; \mathrm{CEI}_{12}, \mathrm{CEI}_{12} 1.0 \times 10^{-5} \mathrm{M} ; \mathrm{CEI}_{\beta 7}$, $\mathrm{CEI}_{\beta 7} 2.0 \times 10^{-6} \mathrm{M} \mathrm{CEI}_{\beta 7} \times 3, \mathrm{CEI}_{\beta 7} 6.0 \times 10^{-6} \mathrm{M} ; \mathrm{CEI}_{5}$, $\mathrm{CEI}_{5} 7.8 \times 10^{-7} \mathrm{M} ; \mathrm{CEI}_{5} \times 6, \mathrm{CEI}_{5} 4.7 \times 10^{-6} \mathrm{M}$.

inhibitors). $\mathrm{CEI}_{\beta 7}$ and $\mathrm{CEI}_{5}$, however, had little bradykinin-potentiating activity at the concentration of the same proportion of the 
Table I. Amino Acid Sequence and ID $_{50}$ Value of ACE Inhibitors

\begin{tabular}{llcc} 
& \multicolumn{1}{c}{ Amino acid sequence } & ID $_{50} \mu \mathrm{M}$ & Ref. \\
\hline $\mathrm{CEI}_{12}$ & Phe-Phe-Val-Ala-Pro-Phe-Pro-Glu-Val-Phe-Gly-Lys & 77 & 6 \\
$\mathrm{CEI}_{\beta 7}$ & Ala-Val-Pro-Tyr-Pro-Gln-Arg & 15 & This paper \\
$\mathrm{CEI}_{5}$ & Phe-Phe-Val-Ala-Pro & 6.0 & This paper \\
$\mathrm{SQ} \mathrm{2}_{20881}$ & Pyr-Trp-Pro-Arg-Pro-Gln-Ile-Pro-Pro & 0.50 & 1 \\
$\mathrm{BP}-\mathrm{B}$ & Pyr-Gly-Leu-Pro-Pro-Arg-Pro-Lys-Ile-Pro-Pro & 3.3 & 2 \\
BP-C & Pyr-Gly-Leu-Pro-Pro-Gly-Pro-Pro-Ile-Pro-Pro & 17 & 2 \\
\hline
\end{tabular}

BP-B, bradykinin-potentiator B; BP-C, bradykinin-potentiator C; Pyr, pyroglutamic acid.

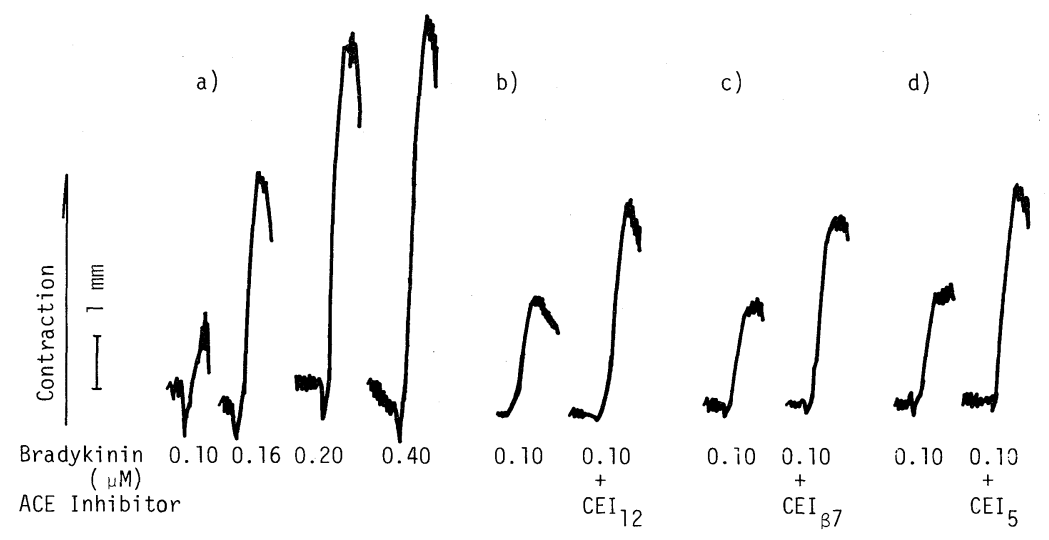

FIG. 4. Bradykinin-potentiating Activity of ACE Inhibitors on the Ileum of Rat.

Bradykinin-potentiating activity was assayed by the contraction of the ileum of rat in aerated Tyrode solution at $30^{\circ} \mathrm{C}$.

(a): To $5 \mathrm{ml}$ volume of muscle bath $0.10 \sim 0.40 \mu \mathrm{M}$ bradykinin was added.

$(b \sim d)$ : ACE inhibitors (at the concentration of $0.13 \times \mathrm{ID}_{50}$ ) were added just before addition of $0.10 \mu \mathrm{M}$ bradykinin.

b), $\left.\left.10 \mu \mathrm{M} \mathrm{CEI}_{12} ; \mathrm{c}\right), 2.0 \mu \mathrm{M} \mathrm{CEI}{ }_{\beta 7} ; \mathrm{d}\right), 0.78 \mu \mathrm{M} \mathrm{CEI}_{5}$.

$\mathrm{ID}_{50}$ value (i.e. $0.13 \times \mathrm{ID}_{50}$ value of each peptide), but $\mathrm{CEI}_{\beta 7}$ and $\mathrm{CEI}_{5}$ increased the effect of bradykinin when a higher concentration was added to the muscle bath.

Thus, $\mathrm{CEI}_{5}$ and $\mathrm{CEI}_{\beta 7}$ are weak as bradykinin-potentiator in comparison with its inhibitory activity on ACE.

Bradykinin-potentiating activity of ACE inhibitors on the ileum of rat.

All ACE inhibitors derived from casein potentiated the effect of bradykinin on the contraction of the isolated ileum of rats at the indicated concentration (i.e. $0.13 \times \mathrm{ID}_{50}$ value of each ACE inhibitor) (Fig. 4). Thus, ACE inhibitors were more effective on the ileum than on the uterus. The effects of these in- hibitors lasted for more than 90 min even after the inhibitor was washed out from the organ bath. Figure 5 (sensitizing activity of $\mathrm{CEI}_{12}$ on the ileum of rat) shows the effect of $20 \mu \mathrm{M}$ $\mathrm{CEI}_{12}$ lasted for $90 \mathrm{~min}$ after $\mathrm{CEI}_{12}$ was washed out from the bath.

\section{DISCUSSION}

Many of the natural inhibitors derived from snake venom have Pro-Pro or Ala-Pro sequences at their $\mathrm{C}$-terminal. $\mathrm{CEI}_{5}$ also has an Ala-Pro sequence at its C-terminal. Therefore, the inhibitory activity of $\mathrm{CEI}_{5}$ is more potent than $\mathrm{CEI}_{12}$, and the $\mathrm{ID}_{50}$ value of $\mathrm{CEI}_{5}$ is almost equal to the bradykinin-potentiator derived from the venom of Agikistrodon halys 


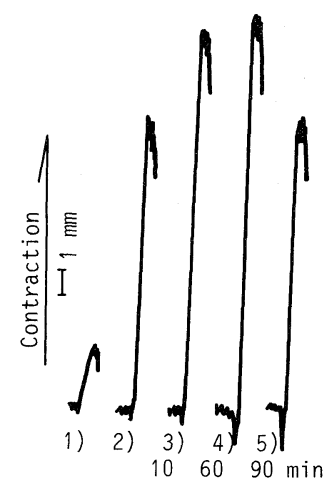

FIG. 5. Sensitizing Activity of $\mathrm{CEI}_{12}$ on the Ileum of Rat.

Sensitizing activity was assayed by the contraction of the ileum of rat in aerated Tyrode solution at $30^{\circ} \mathrm{C}$.

(1): To $5 \mathrm{ml}$ volume of muscle bath $0.1 \mu \mathrm{M}$ bradykinin was added, and contraction was measured.

(2): Then the ileum was washed with Tyrode solution. $20 \mu \mathrm{M} \mathrm{CEI}_{12}$ and $0.1 \mu \mathrm{M}$ bradykinin were added, and contraction was measured.

$(3 \sim 5)$ : And then, the ileum was washed 5 times with Tyrode solution. 10, 60, and 90 min later after washing, $0.1 \mu \mathrm{M}$ bradykinin was added, and contraction was measured.

blomhoffii (The $\mathrm{ID}_{50}$ value of these inhibitors were listed in Table I). On the other hand, $\mathrm{CEI}_{12}$ and $\mathrm{CEI}_{\beta 7}$ do not have a common structure at their $\mathrm{C}$-terminals. However, it is unclear which amino acid residues are important for their inhibitory activity.

ACE is a zinc metalloprotein, and similar in many ways to carboxypeptidase A of bovine pancreas, but our inhibitors (at the concentration of $400 \mu \mathrm{M}$ ) did not inhibit carboxypeptidase A.

Bradykinin-potentiating activity was measured using the guinea pig ileum by many investigators. ${ }^{2,8)}$ In the rat uterus, bradykinin potentiation by ACE inhibitor was less investigated, because it requires a higher concentration of ACE inhibitor than the guinea pig ileum. ${ }^{2)}$ Our ACE inhibitors potentiated the activity of bradykinin on the uterus of rat. But the concentration of $\mathrm{CEI}_{\beta 7}$ and $\mathrm{CEI}_{5}$ required for the potentiation on the uterus were higher than required on the ileum.
Cushman et al. measured the concentration of ACE in tissues of the rat. They reported that high specific activities of ACE were found in the lung and ileum of rats, and the uterus contained some peptidases other than ACE. $\left.{ }^{9}\right)$ Our data may reflect the concentration of ACE in the tissues of rats.

Kato and Suzuki observed that the response of the isolated ileum of guinea pig to bradykinin was enhanced by bradykinin-potentiator $\mathrm{B}$ even after this peptide was washed out. ${ }^{2)}$ This residual effect was termed 'sensitization'. All our ACE inhibitors had this sensitizing activity on the ileum of rats. SQ20881 and $\mathrm{CEI}_{5}$ also showed this effect on the uterus of rats, however, $\mathrm{CEI}_{12}$ and $\mathrm{CEI}_{\beta 7}$ showed little of this effect, for unknown reasons.

Recently, it has been reported that there are biologically active peptides in enzymatic hydrolysates of casein, such as $\beta$-casomorphin ${ }^{10)}$ and exorphin. ${ }^{11)}$ Our peptides derived from casein also inhibit ACE, and it is interesting that biologically active peptides are made from food by enzymes in the digestive tract.

\section{REFERENCES}

1) M. A. Ondetti, N. J. Williams, E. F. Sabo, J. Pluščec, E. R. Weaver and O. Kocy, Biochemistry, 10, 4033 (1971).

2) H. Kato and T. Suzuki, Biochemistry, 10, 937 (1971).

3) D. W. Cushman, H. S. Cheung, E. F. Sabo and M. A. Ondetti, Biochemistry, 16, 5484 (1977).

4) A. A. Patchett et al., Nature, 288, 280 (1980).

5) R. E. Galardy, V. Kontoyiannidou-Ostrem and Z. P. Kortylewicz, Biochemistry, 22, 1990 (1983).

6) S. Maruyama and H. Suzuki, Agric. Biol. Chem., 46, 1393 (1982).

7) T. Koide, "Seikagaku Jikken Koza," Vol. 1, ed. by T. Yamakawa and K. Imahori, Tokyo Kagakudozin Press, Tokyo, 1976, p. 158 (in Japanese).

8) S. H. Ferreira, D. C. Bartelt and L. J. Greene, Biochemistry, 9, 2583 (1970).

9) D. W. Cushman and H. S. Cheung, Biochim. Biophys. Acta, 250, 261 (1971).

10) V. Brantl, H. Teschemacher, A. Henshen and F. Lottspeich, Hoppe-Seyler's Z. Physiol. Chem., 360, 1211 (1979).

11) S. Loukas, D. Varoucha, C. Zioudrou, R. A. Streaty and W. A. Klee, Biochemistry, 22, 4567 (1983). 